\title{
Comment on "First records of syn-diagenetic non-tectonic folding in Quaternary thermogene travertines caused by hydrothermal incremental veining" by Billi et al. Tectonophysics 700-701 (2017) 60-79
}

** M. Cihat Alçiçek ${ }^{1}$, Hülya Alçiçek ${ }^{1}$, Erhan Altunel ${ }^{2}$, Concha Arenas $^{3}$, Paul Bons ${ }^{4}$, Andrea Brogi ${ }^{5, *}$, Enrico Capezzuoli ${ }^{6}$, Tamara de Riese ${ }^{4}$, Giovanna Della Porta ${ }^{7}$, Anna Gandin ${ }^{8}$, Li Guo ${ }^{9}$, Brian J ones ${ }^{10}$, Volkan Karabacak ${ }^{11}$, Stephen Kershaw ${ }^{12}$, Domenico Liotta ${ }^{5}$, Andrea Mindszenty ${ }^{13}$, Martyn Pedley 14, Paola Ronchi ${ }^{15}$, Rudy Swennen ${ }^{16}$, Ugur Temiz ${ }^{17}$

${ }^{1}$ University of Pamukkale, Department of Geology, 20070, Denizli (Turkey)

${ }^{2}$ University of Eskişehir Osmangazi, Department of Geological Engineering, 26040 Eskişehir (Turkey)

${ }^{3}$ University of Zaragoza, Department of Earth Sciences, Calle Pedro Cerbuna, 12. 50009 Zargoza (Spain).

${ }^{4}$ University of Tübingen, Department of Geosciences, Wilhelmstr. 56, 72074 Tübingen, (Germany)

${ }^{5}$ University of Bari, Department of Earth and Geoenvironmental Sciences. Via Orabona 4, 70125 Bari (Italy)

${ }^{6}$ University of Perugia, Department of Physics and Geology. Via Pascoli, 06123 Perugia (Italy)

${ }^{7}$ University of Milan, Department of Earth Sciences. Via Mangiagalli 34, 20133, Milan (Italy)

${ }^{8}$ University of Siena, Department of Physics, Earth and Environmental Sciences, 53100 Siena, (Italy)

${ }^{9}$ CASP, 181A Huntingdon Road, Cambridge, CB3 ODH, (United Kingdom)

${ }^{10}$ University of Alberta, Department of Earth and Atmospheric Science, Edmonton, Alberta (Canada)

${ }^{11}$ University of Eskişehir Osmangazi, Department of Geological Engineering, 26040 Eskişehir (Turkey)

12 University of Brunel, Department of Life Sciences, Uxbridge, Middlesex, UB8 3PH (United Kingdom)

${ }^{13}$ University of Eötvös L., Department of Physical and Applied Geology, 1117 Budapest, Pázmány P. st.1/c (Hungary)

${ }^{14}$ University of Hull, Geology Group, School of Environmental Sciences, Hull, HU6 7RX (United Kingdom)

${ }^{15}$ ENI Upstream and Technical Services, Via Emilia 1, 20097, San Donato Milanese, (Italy)

${ }^{16}$ University of Leuven, Department of Earth and Environmental Sciences, KU Leuven, (Belgium)

${ }^{17}$ University of Bozok, Department of Geological Engineering, 66100 Yozgat (Turkey)

* Corresponding author: Tel. +39080 5442576; e-mail: andrea.brogi@uniba.it

** Authors are listed alphabetically 


\section{Abstract}

Billi et al. (2017) proposed a new interpretation for the origin and internal structure of thermogene travertine deposits. On the basis of evidence from two quarries located in southern Tuscany (Italy), they interpreted some travertine beds as calcite veins and argued that undulating travertine beds formed by syn-diagenetic (i.e. non-tectonic) folding that was caused by laterally-confined volume expansion caused by incremental veining. They assumed that such a process causes changes to the rock properties, including porosity reduction, rock strengthening, and age rejuvenation. The interpretations by Billi et al. (2017) challenge and question the current understanding and interpretation of thermogene travertine deposits. This understanding, based on numerous studies since the 1980s, is that these deposits form from thermal water flowing downslope, and precipitating calcium carbonate. Here, we explain how the comparison with active depositional systems is essential for the understanding the origin of structures in older, inactive travertine deposits, such as those studied by Billi et al. (2017). We further argue that the three-dimensional setting of travertine deposits should be taken into account in order to discuss the possible development of secondary structures. Indeed travertine deposition on slopes typically leads to the formation of terraced morphologies with pools bordered by rounded rims and separated from each other by steep walls. The resulting three-dimensional structures can be misinterpreted as asymmetric folds in two-dimensional views (i.e., in saw-cut walls of quarry). In this paper we debate the interpretations offered by Billi et al. (2017) and their criteria to recognise syn-diagenetic, non-tectonic folds in travertine deposits, and explain why many of their ideas are questionable.

\section{Key words}

travertine facies, travertine depositional geometry, deformational processes, calcite veins, enterolithic structures, age rejuvenation 


\section{Introduction}

The recent literature on travertine (i.e. thermogene terrestrial carbonate) has made use of this deposit as a proxy for palaeo-environmental (Bertini et al. 2008; Ricci et al., 2015) and climate change reconstructions (Sturchio et al., 1994; D'Argenio et al. 1995; Rihs et al., 2000; Soligo et al., 2002; Mesci et al., 2008; Faccenna et al., 2008; Zentmyer et al., 2008; Sierralta et al., 2010; Brogi et al., 2010), neotectonic and palaeoseismological analyses (Altunel and Hancock, 1993a, 1993b; Çakır, 1999; Hancock et al., 1999; Brogi, 2004; Altunel and Karabacak, 2005; Uysal et al., 2007; 2009; Mesci et al., 2008; Brogi and Capezzuoli, 2009, 2014; Temiz et al., 2009; 2013; Brogi et al., 2010, 2012, 2014a, 2014b, 2016; Altunel and Karabacak, 2005; Uysal et al., 2007; 2009; Hancock et al., 1999; Temiz et al., 2009; 2013; Temiz and Eikenberg, 2011; Cakir, 1999; Mesci et al., 2008), geothermal exploration (Navarro et al., 2011; Pasvanoğlu and Chandrasekharam, 2011; Alçiçek et al. 2016; Brogi et al., 2016; Alçiçek et al., 2017), elemental biomediation processes analyses (Folk, 1994; Bonny and Jones, 2003; Fouke et al., 2003; Rogerson et al., 2014), and natural $\mathrm{CO}_{2}$ degassing evaluation (Shipton et al., 2005; Uysal et al., 2011; Frery et al., 2016). These applications coupled with the fact that travertine is a rare carbonate deposit, makes it a precious archive of information from many different scientific perspectives. The conventional approach for the study of these deposits requires many different mandatory steps, including: (i) reconstruction of the three-dimensional geometry of the travertine deposit and its evolution through time; (ii) reconstruction of the depositional architectural setting of the different depositional stages; and (iii) sedimentary facies analysis that includes interpretation of sedimentary facies, their lateral relationships, and the processes associated with each depositional setting. The latter step is critical because it allows the reconstruction of the environmental features that controlled the travertine formation and the related sedimentary processes dictating its origin. Accurate facies interpretation depends on careful observations that follow a well-established methodology, which has been fully documented in a considerable number of previous studies (e.g. Chafetz and Folk, 1984; Guo and Riding, 1992, 1994, 1998; Chafetz and Guidry, 1999; Pentecost, 2005; Jones and Renaut, 2010; Gandin and 
Capezzuoli, 2014).

Failure to follow the established protocols can lead to misinterpretations. This is, in our opinion, the case presented in the paper by Billi et al. (2017) who analysed Pleistocene (thermogene) travertine deposits exposed in saw-cut walls of two quarries (see also: Ronchi and Cruciani, 2015), located in southern Tuscany (Italy). They interpreted structures in those walls as syndiagenetic, non-tectonic veins and folds and provided nine criteria for discriminating secondary structures (i.e. post-depositional syn-diagenetic processes such as veining, folding, or rejuvenation actions) from primary structures (i.e. related to the sedimentary evolution) in travertine deposits. We question these criteria, which in our view do not sufficiently take in to account the present knowledge on travertine formation. Herein, our comments aim to fill this gap and to favour a solid consideration of the comparison between active and fossil travertine depositional systems.

\subsection{Questions for comments}

Billi et al. (2017, their Figs. 3, 4) argued that the syn-diagenetic (i.e. nontectonic) folding of travertine was the result of laterally-confining volume expansion that was caused by incremental hydrothermal veining. Their idea, based on the study of Gratier et al. (2012), implied that undulating travertine beds are unreliable indicators of the sedimentary environment (and its evolution through space and time) in which the travertine accumulated. Furthermore, a consequence of their hydrothermal-veining interpretation is age rejuvenation of travertine deposits with implications for geochronological results and modification of travertine strength and porosity, and effective impacts on permeability evaluations. On the basis of these considerations, Billi et al. (2017) proposed "a list of significant criteria to discriminate secondary from primary structures and to identify rejuvenation processes" to explain the occurrence of: (i) radiometrically-dated structures that are younger than overlying ones; (ii) downward growth of crystals; (iii) veins overprinting/cutting through overlying or underlying beds; (iv) relicts of 
primary porous travertine beds between radiating vein crystals; (v) increasingly deformed primary structures such as beds or pores towards veins and folds; (vi) bed-normal foliations and second-order folds nested inside larger folds; (vii) polyphase folding including overturned folds with refolded limbs; (viii) stylolite surfaces parallel and stylolite teeth normal to vein planes; (ix) post-depositional non-karstic voids between folded and flat veins and beds, outlining the occurrence of post-depositional detachment mechanisms between adjacent beds. We criticize the interpretation of these points. The following text is therefore organized in separate sections, each of which focuses on those aspects of the interpretations that are crucial for a wellconstrained facies analysis and reconstruction of the depositional environments. In so doing, we underline and stress the lessons that have been learnt from the analysis of active travertine depositional systems, which collectively provide clear insights into the processes that define the depositional geometry and development of travertine deposits.

\section{Calcite veins versus travertine beds/layers (crystalline crusts)}

This section discusses the points 2 to 5 of the list of criteria provided by Billi et al. (2017) for the interpretation of travertine deposits.

Billi et al. (2017) described the geometric relation between the porous travertine beds and the growth direction of the constituent calcite crystals (Billi et al., 2017, their Figs. 4d, 4e and 11d) in the crystalline travertine beds (also termed crystalline crusts by Guo and Riding, 1998 and references therein). Based on this, Billi et al. (2017) argued that the porous travertine beds formed as a primary deposit, whereas the crystalline crusts developed as calcite veins that post-dated deposition of the travertine. This interpretation challenges the fact that crystalline crusts are primary carbonate precipitates that develop at the depositional surface as a result of $\mathrm{CO}_{2}$ degassing from carbonate-rich waters during their flow (Fig. 1). Thus, crystalline crusts are formed as a variety of calcite/aragonite crystals (feather, fan, dendrites; see Jones and Renaut, 1995; 2010 for a review; Jones et al., 2000, 2005). Furthermore, this clarifies the definition of travertine as a primary bedded thermogene deposit 
(Chafetz and Folk, 1984; Jones and Renaut, 1995, 2008; Jones et al., 1996, 2000, 2005; Guo and Riding, 1998; Jones and Renaut, 1995, 2008; Jones et al., 1996, 2000, 2005; Rainy and Jones, 2009; Gandin and Capezzuoli 2014; Della Porta, 2005; Croci et al., 2016; Della Porta et al., 2017) where the intercalation of porous (Fig. 2) and crystalline deposits is a characteristics of travertine spring deposits (Riding, 1991; Pedley, 1990; Flügel, 2004; Pentecost, 2005; Pedley, 2009; Brogi et al., 2010; Capezzuoli et al., 2014; Pola et al 2013; Gandin and Capezzuoli, 2014; Gradzinski et al., 2014).

Veins (see Bons et al., 2012 for a review) in travertine deposits (Fig. 3) are formed of different types of crystals (Altunel and Karabacak, 2005; Uysal et al., 2009, 2011; Rimondi et al., 2015; Brogi et al., 2014a; Brogi et al., 2016) and fill cracks that cut across layers (Fig. 3a-f) or follow bedding surfaces (Fig. 3g-i) (e.g. Altunel and Hancock, 1993a, 1993b; Altunel and Karabacak, 2005; Mesci et al., 2008; Uysal et al., 2009; 2011; Brogi et al., 2016; Brogi et al., 2017; Selçuk et al., 2017).

The growth of bed-parallel veins (i.e. sub-horizontal veins that opened against the force of gravity) has been attributed to: i) the crystallization force of calcite triggered by $\mathrm{CO}_{2}$ degassing at depths of 1-10 m (Gratier et al., 2012); ii) repeated injections of high-pressure hydrothermal fluids (pressure exceeding the weight of the overlying rocks volume, Brogi et al., 2016) during seismic events (Uysal et al., 2007; Altunel and Karabacak, 2005; Uysal et al., 2007; Brogi and Capezzuoli, 2014; Brogi et al., 2017) and/or (iii) by climate induced pressure variations within the geothermal reservoir at depth (Uysal et al., 2009). The textures of such veins (Fig. 4), however, are completely different from the ones reported by Billi et al. (2017, their Fig. 4e). In their case, the veins are formed of needle-like crystals, rows of palisade, fibrous or prismatic crystals, generally arranged in tight palisades with straight extinction or clusters of ray-shaped fans (as described in Folk et al., 1985; Atabey 2002; see also Flügel, 2004, Jones and Renaut, 2010, Gandin and Capezzuoli, 2014, for review on the petrographic characteristics of calcite veins and travertine). They are typical of precipitates associated with pools and terraces (Figs $\mathbf{1}$ and 2). Such crystalline layers typically consist of dense crystalline dendrites or crusts (some could also be shrubs as illustrated in Tivoli, nearby Rome, Italy, 
as documented by Erthal et al., 2017) that can laterally, or vertically, grade into the porous deposits where numerous voids from bubbles and other origins are present (Fig. 2). This arrangement is readily evident in present-day active travertine deposits all over the world and defines well-documented depositional geometries such as dams, rims, and terraces (e.g. Pamukkale, Turkey; Mammoth Hot Springs, USA; Huanglong, China; Badab-e surt, Iran, Saturnia, Italy; Rapolano Terme, I taly; see also Pentecost, 1995, 2005; Ford and Pedley, 1996 for a review). Similar depositional structures are present in caves, where the same process can be active (rimstone dams; Ford and Williams 2007).

These well-documented relationships between porous and crystalline beds (Figs 2 and 5 for active and fossil examples, respectively) also include what Billi et al. (2017, their Fig. 5a and 5b) described as "chimney-like veins". In their photographs, it is apparent that the brownish porous layers pass laterally into the dense crystalline layers ("veins" in Billi et al., 2017), with visible interfingering relationships. This cannot, however, be attributed to a subsequent deformational event. Moreover, their Fig. $4 \mathrm{f}$ shows that the boundary of the crystalline beds with the porous micritic deposits is diffuse, underlining the absence of mechanical/physical discontinuities that would be expected if this were caused by subsequent pressure-induced deformation as proposed by Billi et al. (2017).

Finally, Billi et al. (2017) based most of their arguments on evaluation of the direction of calcite crystals growth. Conversely, the criteria used to establish the growth-orientation of the travertine beds should be considered with care, because the fan-like crystal arrangement (Fig. 1d-g) may result in different apparent directions within the same bed (e.g. Billi et al. 2017, their Figs S25 and S34).

Billi et al. (2017) suggested that the development of calcite veins caused the reduction of primary porosity (their Fig. $5 \mathrm{c}$ ), as indicated by the flattened pores, which they assumed were originally almost spherical (see their section 3.1.3). It is important to stress, however, that the classical, spherical "coated bubbles" found in many travertine deposits (Guo and Riding, 1998; Gandin, 2013; Gandin and Capezzuoli, 2014 for a review) are formed by the encrustation of bubbles with a thin coating of calcite caused by $\mathrm{CO}_{2}$ degassing 
(see Schreiber et al., 1981; Chafetz et al., 1991 and Pentecost, 2005 for a complete description of this depositional process). When this is the case, the bubbles are externally characterized by thin calcite rims. Consequently, this type of porosity is commonly concentrated in small volumes (Fig. 2). Otherwise, most pores in travertine (as all the pores discussed in Billi et al., 2017) are formed from photosynthetic oxygen that is produced by microbial activity and are common in microbial deposits (e.g. Folk et al., 1985; Riding, 1991; Rainey and Jones, 2009). Given that these are not coated by a calcite rim, their shape is highly variable (e.g. Gandin and Capezzuoli, 2014 for a comparison) and reflects the balance among gas pressure, gravity, and weight of the microbial mat. Thus, the pore shape cannot be used to evaluate deformation in travertine deposits, because their initial shape is highly variable and unpredictable. It follows that the interpretation of the crystalline beds as calcite veins that postdated the original travertine deposits is difficult to accept.

\section{2D-view of crystalline crusts versus folded travertine}

Hereafter we discuss the points 6 and 8 of the list of criteria that Billi et al. (2017) proposed for the interpretation of travertine deposits.

Billi et al. (2017) argued that undulations in the travertine beds are syndiagenetic folds that developed during the progressive and incremental formation of syntaxial, bedding-parallel, calcite veins. In active spring depositional environments (Fig. 1) the undulation in travertine deposits (undulated layers) is a natural consequence of subaerial deposition on variably inclined surfaces (i.e. slopes and dammed zones), through pools and rims, producing terraced surfaces (Fig. 2). This is well constrained by threedimensional observations in most active and fossil travertine (and tufa) depositional systems (Italy: Chafetz and Folk, 1984; Guo and Riding, 1998; D'Argenio et al., 1981, D'Argenio and Ferreri, 1987,1988; Hungary: Scheuer and Schweitzer, 1981; Kele et al., 2008; Claes et al., 2017, Török et al., 2017; Turkey: Altunel and Hancock, 1993a; 1993b; Khatib et al. 2014; Lebatard et al., 2014; Claes et al., 2015; Tunisia: Henchiri et al., 2017; China: Liu et al., 
1995; Lu et al., 2000; Central Italy: Capezzuoli et al., 2014; Della Porta, 2015; Croci et al., 2016; Della Porta et al., 2017; Violante et al., 1994a, 1994b; Central Western Carpathians, Slovakia: Gradzinski et al., 2014; USA: Fouke et al., 2000; different places: Pentecost 2005; Alonso-Zarza and Tanner 2010; Arenas-Abad et al. 2010; Jones and Renaut 2010).

Taking a different viewpoint, Billi et al. (2017), evaluating geometries based on 2D-cross sections, interpreted the undulatory and terraced travertine beds as asymmetric folds, and argued that the typical aggradational and slightly progradational geometry of the pool/rims are the result of second-order folds. They did not consider the well-established fact that travertines are selfregulating systems, that can modify their own depositional environment, which may result in changes in the attitude of the strata with, or even without, any syn- or post-depositional tectonic deformation.

Ronchi and Cruciani (2015), who studied the same quarries as Billi et al. (2017), interpreted the terraced travertine as an effect of the travertine deposition on pre-existing slopes. Billi et al. (2017) did not provide convincing reasons for modifying the interpretations proposed by Ronchi and Cruciani (2015) and the numerous of studies from other areas that show the same features (Chafetz and Folk, 1984; Guo and Riding, 1998: D'Argenio et al. 1981; Scheuer and Schweitzer, 1981; Altunel and Hancock, 1993a; Khatib et al. 2014; Lebatard et al., 2014; Claes et al., 2015; Henchiri et al., 2017; Liu et al., 1995; Lu et al., 2000; Pentecost, 2005 for a review; Capezzuoli et al., 2014, Della Porta, 2015; Croci et al., 2016; Della Porta et al., 2017).

Billi et al. (2017, their Figs $5 \mathrm{f}$ and $5 \mathrm{~g}$ ) also described folds with evident hinge thickening that affect the calcite veins. They proposed for a composite deformational process, with initial formation of mostly sub-horizontal calcite veins that was followed by folding of the previously developed veins and parallel porous travertine beds. They also argued that there was a subhorizontal tectonic foliation developed in association with the second-order folds developed only in the vertical fold limb of the first order structures (see their Fig. $5 \mathrm{~g}$ and 6 ). In addition, their Fig. S10 is meant to show refolded structures resulting from at least two folding events, with deformation of the limb of a larger overturned fold. 
The folds, refolded folds, and related tectonic foliation proposed by Billi et al. (2017) have already been unequivocally described as primary depositional features (cf. Chafetz and Folk, 1984; Hammer et al., 2010), but they did not discuss or refute this interpretation. The undulatory beds that they interpreted as first-order folds (and refolded folds) are explained as an effect of the plane view orientation in a travertine cascade environment (Fig. 6a-b). Their "second order folds" and associated "axial planar tectonic foliations" (cf. their Figs $6 b, 6 d$ and 6f) can be explained as microterraces (Fig. 6c-e) that formed on spring slopes (e.g. "rimstone pool" of Warwick, 1952, to "terracette" of Bargar, 1978 and Guerts et al., 1992; "minidams" of Pentecost 2005 and Jones and Renaut 2010; "microterracettes" in Hammer et al., 2010).

The 2D-features displayed on the quarry walls by Billi et al. (2017, their Fig. 5 and 6) are recognizable in all present-day depositional systems (Fig. 2). This circumstance reinforces the argument that these are really vertical crosssections through fossil pool rims (i.e. microterraces) and cascades that formed by natural (i.e. primary) sedimentary processes (Fig. 6); they are not (second-order) folds as suggested by Billi et al. (2017). In addition, it should also be remembered that the shape, size, and distance between micro- and macro-terraces depend on local depositional features (e.g. Riding, 1991; Pentecost 2005: see Fig. 16; Goldenfeld et al., 2006; Hammer et al. 2005, 2007, 2010; Veysey and Goldenfeld, 2008), not only for travertine, but also for all flowstone deposits (speleothems, tufa, siliceous sinter).

Billi et al. (2017) claimed a further explanation for their minor folds. They suggested that the process that produced the small-scale folding is analogous to the process that produces enterolithic and/or tepee structures, which are commonly found in evaporitic deposits. Enterolithic structures (i.e. irregular, highly-non-cylindrical tight to open folds) are typical of sabkha environments and cannot develop in travertine deposits. Such structures are produced by localized changes in volume after evaporite deposition (cf. Gandin and Wright, 2007). This syn- to meta-depositional deformation is induced by the chemical transformation of the sulphates, such as the swelling of anhydrite during hydration to gypsum. Gypsum and anhydrite nodules form through the capillary system within the upper phreatic zones beneath the sabkha surface, 
displacing and replacing sediment under pressurized saline fluids that are flowing through pores due to evaporative capillarity (Tucker, 1988; Warren, 1999, 2006; Flügel, 2004; Gandin and Wright, 2007). These intrasediment crystals grow in a matrix of fine sediment (i.e. lime mud, clays), where the nodules grow and coalesce to form the enterolithic structures. Thermogene travertine, however, with primary precipitation of calcite/aragonite, has a completely different chemical and mineralogical composition, as well as an internal organisation, and its deposition occurs in totally different environments. Thus, there is no basis for assuming that travertine deposits may develop in the same manner as evaporites and therefore, extreme care should be taken when comparing the two.

\subsection{Mechanics of travertine folding}

This section discusses the points 7 and 9 of the list of criteria proposed by Billi et al. (2017).

Travertine forms at the subaerial surface, where deposition and lithification processes are almost contemporaneous (Pentecost, 1995). Travertine is composed largely of calcite and/or aragonite, carbonate minerals that are brittle under low temperature conditions $\left(<250^{\circ} \mathrm{C}\right.$, Rutter, 1972). Furthermore, the maximum thickness of travertine in slope environments does not exceed a few tens of meters as found in several areas worldwide (Pentecost 1995; Guo et al., 1996; Hancock et al., 1999; Brogi, 2004; Brogi et al., 2010; Ronchi and Cruciani, 2015; Khatib et al. 2014; Lebatard et al., 2014; Claes et al., 2017). This implies that travertine can only be affected by deformation at, or near the surface. It follows that the boundary conditions ( $P$, $\mathrm{T}$ and/or significant content of interstitial fluids) required to obtain highly noncylindrical folds (Billi et al., 2017, their Fig. 5j) are not present. In this view, the flattened, squeezed, dragged pores as Billi et al. (2017) described close to the fold hinges, veins and folded veins (Figs. 3b, 5c, d, S6, S11, S12, S14, S23, and S35), are not the result of the folding mechanism but are primary sedimentary features, as discussed above.

Second-order folds attributed to folding imply bedding viscosity contrast and/or thickness variations of a flexural slip folding mechanism. This is 
normally produced in a multi-layered succession, which does not seem to apply to travertine formed by carbonate precipitation on a terraced slope. In order to explain fold hinge thickening and occurrence of second-order folds and foliations, Billi et al. (2017, their Figs. 5f, g, and 6) considered the BiotRamberg's buckling equation (their Eq. 1). Billi et al. (2017) used the buckling equation for single-layer folding and an assumed Newtonian viscosity to obtain a viscosity contrast of about 1.5 to 4 . They did not report the amplitudes of the folds $(A)$ in relation to the fold wavelength $(\lambda)$, which is shorter than the arc length ( $L$ ) that they used. Although it is difficult to ascertain how layer thicknesses $(t)$ were defined in the multi-layer setting, it seems that a ratio of $A / I \geq 0.25$ is a conservative estimate for the structures. Their reported $L / t$ ratios range from about 4 to 5 . This can be converted to $t / I$ ratios, using $I \geq 2 / 3 \cdot L$, in the range of 0.1 to 0.25 .

$A / \lambda$ versus $t / \lambda$ trends depend on the amount of shortening and viscosity contrast (Fig. 6 in Schmalholz and Podladchikov, 2001; Fig. 2 in Llorens et al., 2013). For single-layer folding, the range of measured ratios would indicate $\geq 50 \%$ shortening and a viscosity ratio between 25 and 250 . At the very low viscosity contrast, as used by Billi et al. (2017), folds grow very slowly in amplitude as layer thickening dominates. To achieve $A / \lambda>>0.25$, a very high strain would be required, but this would result in much higher $t / \lambda$ ratios ( $>>0.5$ ) than the ones observed.

If the buckle fold theory were applicable (which we doubt), the viscosity contrast between the layers in the travertine would need to be much higher than that proposed by Billi et al. (2017). More importantly, the amount of strain needed to achieve the high $A / \lambda$ ratios would be well over $50 \%$ shortening, or in case of constrained volume increase, $>100 \%$ of layer length increase by volume change. In addition, Billi et al. (2017, their Fig. S11) also described bedding-parallel stylolites that are typically associated with dissolution that takes place as a result of overburden loads during deep burial and pressure solution (e.g. Bathurst, 1995; Rolland et al., 2012; Heap et al., 2014; Koehn et al., 2016). Their development is related to the occurrence of local rock mass heterogeneity, occurrence of interlayered/intracrystalline water, dissolution and deposition of dissolved material in extensional veins, 
and a sufficient lithostatic pressure. As shown by Sellier (1979), the pressuredissolution of calcite begins at a depth of about $300 \mathrm{~m}$. In other cases, stylolites have been documented at lesser burial depth, at about $90 \mathrm{~m}$, but only if the limestones have a high clay content (Schlanger, 1964). Taking into account that the travertine deposits described by Billi et al. (2017) were not buried to the depth needed for stylolite formation, we doubt that the structures described by Billi et al. (2017) are stylolites. The 2D-view of the outcrop is again at the base of this misunderstanding: features similar to stylolites can be produced if the saw-cut walls are about orthogonal (or at high angle) to the crystalline crust on slopes that were originally terraced (Fig. 6c-e).

\section{Travertine age rejuvenation}

This part is dedicated to the discussion of the point 1 of the list of criteria provided by Billi et al. (2017), concerning the interpretation of the age of travertine deposits.

Radiometric age dating of travertine is possible by analysis of the U/Th content in the calcite molecules (Taylor and McLennan, 1995 and references therein). U/Th dating of carbonates, younger than 500ka (Walker, 2005), is a sensitive analysis that relies on carefully collected samples (Ku and Liang, 1985). The best dates come from compact, non-porous samples (cf. Carrara et al., 1998; Brogi et al., 2010). Porous travertine samples can be problematical because younger calcite and/or aragonite cements found in the pores may have formed at any time after deposition. The presence of these cement phases can seriously affect the isotopic and geochronological results. Billi et al. (2017, Fig. 7) showed inconsistent age-dating results through a travertine section encompassing "veins" and "porous" travertine. The "inconsistent" ages (samples CP15_8, CP14_2, ST1 and ST3) were used as criteria to validate the "vein" formation. Two samples of travertine layers (lower photo in their Fig. 7b) show an inverted age order, whereas, other samples (upper photos in their Fig. 7b) show upward younging. Following the principle they adopted, however, only one "vein" sample (CP15_8, at the lowest position) is younger 
than the sample that represents the supposed hosting travertine (CP14_25), whereas the other "veins" produced older (CP15_1; CP14_5), or coeval (considering the error range: CP14_2) ages. Interestingly, the uppermost sample of their travertine (ST4) is younger than the underlying (CP13_1-5; CP13_1-4) or quasi coeval (considering the error range: ST1; ST3) to the underlying ST1 and ST3. Although problems seem to exist with the travertine ages, Billi et al. (2017) did not discuss any possible source of errors. The age results, irrespective of how reliable and of high precision in terms of the laboratory methods, cannot be considered as a solid argument to support their model for vein formation.

\section{Conclusions}

Billi et al. (2017) proposed that travertine deposits on horizontal and/or inclined surfaces can subsequently be folded non-tectonically by volumechange processes. Herein, we have shown that: (i) a comparison with active travertine systems and the extensive literature on the topic do not support the interpretations proposed by Billi et al. (2017); (ii) the criteria proposed by Billi et al. (2017) are largely disproved, as most are based on questionable interpretations; iii) the deformation model proposed by Billi et al. (2017) is not supported by evidence that is available from spring systems found throughout the world. Therefore, we do not recommend using the nine criteria that Billi et al. (2017) proposed to distinguish between primary and secondary travertine structures.

\section{Acknowledgements}

We are grateful to the Editor and an anonymous reviewer whose comments and suggestions helped us to improve this comment.

\section{References}


Alçiçek, H., Bülbül, A., Alçiçek, M.C., 2016. Hydrogeochemistry of the thermal waters from the Yenice Geothermal Field (Denizli Basin, SW Turkey). J ournal of Volcanology and Geothermal Research 309, 118-138.

Alçiçek H. Bülbül A. Capezzuoli E. Brogi A. Liotta D. Meccheri M. Riggueri G. Yavuzer İ. Alçiçek M.C. 2017. Origin, evolution and geothermometry of thermal waters in the Gölemezli Geothermal Field, Denizli Basin (SW Turkey).J Volcanol Geotherm Res doi: 10.1016/j.jvolgeores.2017.07.021

Alonso-Zarza, A.M., Tanner, L.H. (Eds.) (2010): Carbonates in Continental Settings, Developments in Sedimentology No.61, Elsevier 378 p.

Altunel, E., Hancock, P.L., 1993a. Morphology and structural setting of Quaternary travertines at Pamukkale, Turkey', Geol. J. 28, 335-346.

Altunel, E., Hancock, P.L., 1993b. Active Fissuring and Faulting in Quaternary Travertines at Pamukkale, Western Turkey. In: Stewart, I.S., Vita-Finzi, C., Owen, L.A. (Eds.), Neotectonics and Active Faulting: Zeitschrift Für Geomorphologie Supplement Vol. 94, pp. 285-302.

Altunel, E., Karabacak, V., 2005. Determination of horizontal extension from fissure-ridge travertines: a case study from the Denizli Basin, southwestern Turkey. Geodin. Acta 18, 333-342.

Arenas-Abad, C., Vazquez-Urbez, M., Pardo-Tirapu, G., Sancho-Marcen, C., 2010. Fluvial and associated carbonate deposits. Ch.3. in Alonso-Zarza, A.M. and Tanner, L.H. (Eds.): Carbonates in Continental settings, Developments in Sedimentology No.61, Elsevier 133-175.

Atabey, E., 2002. The formation of fissure ridge type laminated travertine-tufa deposits microscopical characteristics and diagenesis, Kirşehir, Central Anatolia. Bulletin of the General Directorate of Mineral Research and Exploration of Turkey 123-124, 59-65.

Bargar, K.E., 1978. Geology and thermal history of Mammoth Hot springs, Yellowstone National Park, Wyoming. U.S. Geol Surv Bull 1444, 1-55.

Bathurst, R.G.C., 1995. Burial diagenesis of limestones under simple overburden. Stylolites, cementation and feedback. Bull. Soc. Geol. Fr. 166, 181-192.

Bertini, A., Minissale, A., Ricci, M., 2008. Use of Quaternary travertine of 
central-southern Italy as archives of paleoclimate, paleohydrology and neotectonics. Ital. J. Quatern. Sci. 21, 99-112.

Billi, A., Berardi, G., Gratier, J.P., Rossetti, F., Vignaroli, G., Baykara, M.O., Bernasconi, S.M., Kele, S., Soligo, M., De Filippis, L., Shen, C.C., 2017. First records of syn-diagenetic non-tectonic folding in Quaternary thermogene travertines caused by hydrothermal incremental veining. Tectonophysics $700-$ 701, 60-79.

Bohacs, K.M., Carroll, A.R., Neal, J.E., Mankiewwicz, P.Z., 2000. Lake-basin type, source potential, and hydrocarbon character: an integrated sequencestratigraphic-geochemical framework. In: Gierlowski-Kordesh, E.H., Kerry, K.R. (Eds.), Lake Basins through Space and Time. Am. Assoc. Petrol. Geol. Stud. Geol. vol. 46, pp. 3-33.

Bonny, S., Jones, B., 2003. Microbes and mineral precipitation, Miette Hot Springs, Jasper National Park, Alberta, Canada. Canadian Journal of Earth Sciences 40(11), 1483-1500.

Bons, P.D., Elburg, M. A., Gomez-Rivas, E., 2012. A review of the formation of tectonic veins and their microstructures. Journal of Structural Geology 43, 3362.

Brogi, A., 2004. Faults linkage, damage rocks and hydrothermal fluid circulation: tectonic interpretation of the Rapolano Terme travertines (southern Tuscany, Italy) in the context of Northern Apennines Neogene-Quaternary extension. Eclogae Geol. Helvetiae 97, 307-320.

Brogi, A., Capezzuoli, E., 2009. Travertine deposition and faulting: the faultrelated travertine fissure-ridge at Terme S. Giovanni, Rapolano Terme (Italy). Int. J. Earth Sci. 98, 931-947.

Brogi, A., Capezzuoli, E., 2014. Earthquake impact on fissure-ridge type travertine deposition. Geological Magazine 151, 1135-1143.

Brogi, A., Capezzuoli, E., Aquè, R., Branca, M., Voltaggio, M., 2010. Studying travertines for neotectonics investigations: Middle-Late Pleistocene syntectonic travertine deposition at Serre di Rapolano (Northern Apennines, I taly). Int. J. Earth Sci. 99, 1383-1398.

Brogi, A., Capezzuoli, E., Buracchi, E., Branca, M., 2012. Tectonic control on traver-tine and calcareous tufa deposition in a low-temperature geothermal system (Sarteano, Central Italy). J. Geol. Soc. Lond. 169, 461-476. 
Brogi, A., Capezzuoli, E., Alçiçek, M.C., Gandin, A., 2014a. Evolution of a faultcontrolled travertine fissure-ridge in the western Anatolia extensional province: the Çukurbag fissure-ridge (Pamukkale, Turkey). J. Geol. Soc. Lond. 171, 425441.

Brogi, A., Capezzuoli, E., Martini, I., Picozzi, M., Sandrelli, F., 2014b. Late Quaternary tectonics in the inner Northern Apennines (Siena Basin, southern Tuscany, Italy) and their seismotectonic implication. J. Geodyn. 76, 25-45.

Brogi, A., Alçiçek, C., Yalçıner, C. C., Capezzuoli, E., Liotta, D., Meccheri, M., Rimondi, V., Ruggieri, G., Gandin, A., Boschi, C., Buyuksara, A., Alçiçek, H., Bulbul, A., Baykara, M.O., Shen, C-C., 2016. Hydrothermal fluids circulation and travertine deposition in an active tectonic setting: insights from the Kamara geothermal area (western Anatolia, Turkey). Tectonophysics 680, 211-232.

Brogi, A., Capezzuoli, E., Kele, S., Baykara, M.O., Shen, C.C. 2017. Key travertine tectofacies for neotectonics and palaeoseismicity reconstruction: effects of hydrothermal overpressured fluid injection. Journal of the Journal of the Geological Society. https://doi.org/10.1144/jgs2016-124

Çakır, Z., 1999. Along-strike discontinuity of active normal faults and its influence on quaternary travertine deposition: examples from western Turkey. Turk. J. Earth Sci. 8, 67-80.

Capezzuoli, E., Gandin, A., Pedley, M., 2014. Decoding tufa and travertine (fresh water carbonates) in the sedimentary record: the state of the art. Sedimentology 61, 1-21.

Carrara, C., Ciuffarella, L., Paganin, G., 1998. Inquadramento geomorfologico e climatico ambientale dei travertini di Rapolano Terme (SI). Italian Journal of Quaternary Sciences 11, 319-329.

Carroll, A.R., Bohacs, K.M., 1999. Stratigraphic classification of ancient lakes: balancing tectonic and climatic controls. Geology 27, 99-102.

Chafetz, H.S., Folk, R.L., 1984. Travertines: depositional morphology and the bacterially constructed constituents. J. Sediment. Petrol. 54, 289-316.

Chafetz, H.S., Guidry, S.A., 1999. Bacterial shrubs, crystal shrubs, and raycrystal shrubs: bacterial vs. abiotic precipitation. Sediment. Geol. 126, 57-74.

Chafetz, H.S., Rush, P.R., Utech, N.M., 1991. Microenvironmental controls on mineralogy and habit of $\mathrm{CaCO} 3$ precipitates: an example from active travertine 
system. Sedimentology 38, 107-126.

Claes, H., Soete, J., Van Noten, K., El Desouky, H., Marques Erthal, M., Vanhaecke, F., Ozkul, M., Swennen, R., 2015. Sedimentology, threedimensional geobody reconstruction and carbon dioxide origin of Pleistocene travertine deposits in the Ballık area (south-west Turkey). Sedimentology 62, 1408-1445.

Claes, H., Degros, M., Soete, J., Claes, S., Kele, S., Mindszenty, A., Török, Á., El Desouky, H., Vanhaecke, F., Swennen, R., 2017. Geobody architecture, genesis and petrophysical characteristics of the Budakalasz travertines, Buda Hills (Hungary). Quaternary International

(2016), http://dx.doi.org/10.1016/j.quaint.2016.09.007

Croci, A., Della Porta, G., Capezzuoli, E., 2016. Depositional architecture of a mixed travertine-terrigenous system in a fault-controlled continental extensional basin (Messinian, Southern Tuscany, Central Italy). Sedimentary Geology 332, 13-39.

D'Argenio, B., Ferreri, M., Ferreri, V., Stanzione, D., 1981. Travertines of Southern Italy. Texture, Gechemistry and Sedimentary Model. IAS 2nd Eur. Meeting, Abstracts, 43-44.

D'Argenio, B., Ferreri, V., 1987. A brief outline of sedimentary models for Pleistocene travertine accumulation in Southern Italy. Rend. Soc. Geol. It. 9 167-170.

D'Argenio, B., Ferreri, V.,1988. Ambienti di deposizione e litofacies dei travertini Quaternari dell'Italia Centro-Meridionale. Mem. Soc. Geol. It. 41, 861-868.

D'Argenio, B., Violante, C., Golubic, S., 1995. Travertines as proxies to climate-controlled/controlling carbonates in geologic time. An Introduction. In: Della Porta, G., 2015. Carbonate build-ups in lacustrine, hydrothermal and fluvial settings: comparing depositional geometry, fabric types and geochemical signature In: Bosence, D. W. J., Gibbons, K. A., Le Heron, D. P., Morgan, W. A., Pritchard, T. \& Vining, B. A. (eds), Microbial Carbonates in Space and Time: Implications for Global Exploration and Production. Geological Society, London, Special Publications 418, 17-68.

Della Porta, G., Capezzuoli, E., De Bernardo, A., 2017. Facies character and depositional architecture of hydrothermal travertine slope aprons (Pleistocene, Acquasanta Terme, Central Italy), Marine and Petroleum Geology (2017), 
http://dx.doi.org/10.1016/j. marpetgeo.2017.03.014.

Ubertini, L., Castelli, F., Bras, R.L. (eds.): Climate change and hydrological hazards in the Mediterranean area. Nat. Res.Council of I taly, Perugia, 17-23.

Erthal, M.M., Capezzuoli, E., Mancini, A., Claes, H., Soete, J., Swennen, R., 2017. Shrub morpho-types as indicator for the water flow energy - Tivoli travertine case (central I taly). Sediment. Geology 347, 79-99.

Faccenna, C., Soligo, M., Billi, A., De Filippis, L., Funiciello, R., Rossetti, C., Tuccimei, P., 2008. Late Pleistocene depositional cycles of the Lapis Tiburtinus travertine (Tivoli, Central Italy): possible influence of climate and fault activity. Global Planet. Change 63, 299-308.

Flügel, E., 2004. Microfacies of carbonate rocks. Analysis, interpretation and application. Springer (New York). 976 pp.

Folk, R.L., Chafetz, H.S., Tiezzi, P.A., 1985. Bizarre forms of the depositional and diagenetic calcite in hotspring travertines, Central Italy. In: Schneidermann, N., Harris, P.M. (Eds.) Carbonate Cements, Soc. Econ. Paleont. Miner. Spec. Publ. 36, 349-369.

Folk, R.L., 1994. Interaction between bacteria, nannobacteria and mineral precipitation in hot springs of Central Italy. Geogr. Phys. Quatern. 48, 233246.

Ford, T.D., Pedley, H.M., 1996. A review of tufa and travertine deposits of the world. Earth Sci. Rev. 41, 117-175.

Ford, D., Williams, P., 2007. Karst Hydrogeology and Geomorphology. pp. 562. John Wiley \& Sons Ltd

Fouke, B.W., Farmer, J.D., Des Marais, D.J., Pratt, L., Sturchio, N.C., Burns, P.C., Discipulo, M.K., 2000. Depositional facies and aqueous-solid geochemistry of travertine depositing hot springs (Angel Terrace, Mammoth Hot Springs, Yellowstone National Park, USA). J. Sediment. Res. 70, 265-285.

Fouke, B.W., Bonheyo, G.T., Sanzenbacher, B., Frias-Lopez, J., 2003. Partitioning of bacterial communities between travertine depositional facies at Mammoth Hot Springs, Yellowstone National Park, USA. Canadian Journal of Earth Sciences 40, 1531-1548.

Frery, E., Gratier, J.P., Ellouz-Zimmerman, N., Deschamps, P., Blamart, D., 
Hamelin, B., Swennen, R., 2016. Geochemical transect through a travertine mount: A detailed record of $\mathrm{CO} 2$-enriched fluid leakage from Late Pleistocene to present-day Little Grand Wash fault (Utah, USA), Quaternary International (2016), http://dx.doi.org/10.1016/j.quaint.2016.09.035

Gandin, A., Wright, D.T., 2007. Evidence of vanished evaporites in Neoarchaean carbonates of South Africa. In: Schreiber, B.C., Lugli, S., Babel, M. (Eds.). Evaporites through space and time. Geological Society, London, Special Publications 285, 285-308. ISBN 978-1-86239-232-8

Gandin, A., 2013 Classificazione genetica, caratteri petrologici distintivi e valori isotopici correlati di calcari incrostanti deposti da acque scorrenti (Travertini Calcareous Tufa - Speleotemi). Rend. Online Soc. Geol. It. 27, 10-30.

Gandin, A., Capezzuoli, E., 2014. Travertine: distinctive depositional fabrics of carbonates from thermal spring systems. Sedimentology 61, 264-290.

Geurts, M.-A., Frappier, M., Tsien, H.H., 1992. Morphogenèse des barrages de travertin de Coal Springs, Sud-est du territoire du Yukon, Géogr. phys. et Quaternaire 46, 221-232.

Goldenfeld, N., Chan, P.Y., Veysey, J., 2006. Dynamics of precipitation pattern formation at geothermal hot springs. Phys. Rev. Lett. 96, 254501-1-254501-4.

Gradzinski, M., Wroblewski, W., Dulinski, M. \& Hercman, H., 2014. Earthquake- affected development of a travertine ridge. Sedimentology 61 , 238-263.

Gratier, J.P., Frery, E., Deschamps, P., Røyne, A., Renard, F., Dysthe, D., Ellouz-Zimmerman, N., Hamelin, B., 2012. How travertine veins grow from top to bottom and lift the rocks above them: the effect of crystallization force. Geology 40, 1015-1018.

Guo, L., Riding, R., 1992. Micritic aragonite laminae in hot water travertine crust, Rapolano Terme. Sedimentology 39, 1067-1079.

Guo, L., Riding, R., 1994. Origin and diagenesis of Quaternary travertine shrub fabrics, Rapolano Terme, Central I taly. Sedimentology 41, 499-520.

Guo, L., Riding, R., 1998. Hot-spring travertine facies and sequences, late Pleistocene, Rapolano Terme, Italy. Sedimentology 45, 163-180.

Guo, L., Riding, R., 1999. Rapid facies changes in Holocene fissure ridge hot 
spring travertines, Rapolano Terme, Italy. Sedimentology 46, 1145-1158.

Guo, L., Andrews, J., Riding, R., Dennis, P., Dresser, Q., 1996. Possible microbial effects on stable carbon isotopes in hot-springs travertines. Journal of Sedimentary Research 66, 468-473.

Hammer, Ø., Dysthe, D.K., Jamtveit, B., 2007. The dynamics of travertine dams. Earth Planet. Sci. Lett. 256, 258-263.

Hammer, Ø., Dysthe, D.K., Jamtveit, B., 2010. Travertine terracing: patterns and mecchanisms. In: Pedley, M., Rogerson, M. (Eds.). Tufas, Speleothems and Stromatolites: Unravelling the Physical and Microbial Controls, Geological Society, London, Special Publications 336, 345-355.

Hammer, Ø., Jamtveit, B., Benning, L., Dysthe, D. K., 2005. Evolution of fluid chemistry during travertine formation in the Troll thermal springs, Svalbard, Norway. Geofluids 5, 140-150.

Hancock, P.L., Chalmers, R.M.L., Altunel, E., Çakır, Z., 1999. Travitonics: using travertines in active fault studies. J. Struct. Geol. 21, 903-916.

Heap, M.J., Baud, P., Reuschle, T., Meredith, P.G., 2014. Stylolites in limestones: barriers to fluid flow? Geology 42, 51-54.

Henchiri, M., Ahmed, W.B., Brogi, A., Alçiçek, M.C., Benassi, R., 2017. Evolution of Pleistocene travertine depositional system from terraced slop to fissure-ridge in a mixed travertine-alluvial succession (Jebel El Mida, Gafsa, southern Tunisia). Geodinamica Acta, 29/1, 20-41.

Jones, B., Renaut, R.W., 1995. Noncrystallographic dendrites from hot-spring deposits at Lake Bogoria, Kenya. Journal of Sedimentary Research 65, 1542169.

Jones, B., Renaut, R.W., 2008. Cyclic development of large, complex, calcite dendrite crystals in the Clinton travertine, Interior British Columbia, Canada. Sediment. Geol. 203, 17-35.

Jones, B., Renaut, R.W., 2010. Calcareous spring deposits in continental settings. In: Ed Alonso-Zarza A.M. \& Tanner L.H. "Carbonates in continental settings". Developments in Sedimentology 61, 177-224.

Jones, B., Renaut, R.W., 1996. Influence of thermophilic bacteria on calcite and silica precipitation in hot springs with water temperatures above $90^{\circ} \mathrm{C}$ : evidence from Kenya and New Zealand. Canadian J ournal of Earth Sciences 33, 
Jones, B., Renaut, R.W., Owen, R.B., Torfason, H., 2005. Growth patterns and implications of complex dendrites in calcite travertines from Lysuholl, Snæfellsnes, I celand. Sedimentology 52, 1277-1301.

Jones, B., Renaut, R.W., Rosen, M.R., 2000. Trigonal dendritic calcite crystals forming from hot spring waters at Waikite, North Island, New Zealand. Journal of Sedimentary Research 70, 586-603.

Kele, S., Demény, A., Siklósy, Z., Németh,T., Tóth, M., Kovács, M., 2008. Chemical and stable isotope composition of recent hot-water travertines and associated thermal waters from Egerszalók, Hungary: Depositional facies and non-equilibrium fractionation. Sed.Geo. 211, 53-72.

Koehn, D., Rood, M.P., Beaudoin, N., Chung, P., Bons, P.D., Gomez-Rivas, E. 2016. A new stylolite classification scheme to estimate compaction and local permeability variations. Sedimentary Geology 346, 60-71.

Khatib, S., Rochette, P., Alçiçek, M.C., Lebatard, A.-E., Demory, F., Saos, T., 2014. Etude stratigraphique, sédimentologique et paléomagnétique des travertins de Denizli (Turquie) contenant des restes fossiles quaternaires (Stratigraphic, sedimentological and paleomagnetic study of the Kocabaş travertines, Denizli Basin, Anatolia, Turkey). Anthropologie 118, 16-33.

Ku, T.L., Liang, Z.L., 1985. The dating of impure carbonates with decay- series isotopes. Nucl. Instrum. Methods Phys. Res. 223, 563-571. doi: 10.1016/01675087(84)90710-5.

Lebatard A.-E. Alçiçek M.C. Rochette P. Khatib S. Vialet A. Boulbes N. Bourlès D.L. Demory F. Guipert G. Mayda S. Titov V.V. Vidal L. de Lumley H. 2014. Dating the Homo erectus bearing travertine from Kocabaş (Denizli, Turkey) at at least 1.1 Ma. Earth and Planetary Science Letters 390, 8-18.

Liu, Z., Svensson, U., Dreybrodt, W., Daoxian, Y., Buhmann, D., 1995. Hydrodynamic control of inorganic precipitation in Huanglong Ravine, China: field measurements and theoretical prediction of deposition rates. Geochim. Cosmochim. Acta 59, 3087-3097.

Lu, G., Zheng, C., Donahoe, R.J., Lyons, W.B., 2000. Controlling processes in a $\mathrm{CaCO}_{3}$ precipitating stream in Huanglong Natural Scenic District, Sichuan, China. J. Hydrol. 230, 34-54.

Mesci, B.L., Gursoy, H., Tatar, O., 2008. The evolution of travertine masses in 
the Sivas Area (Central Turkey) and their relationships to active tectonics. Turk. J. Earth Sci. 17, 219-240.

Navarro, A., Font, X., Viladevall, M., 2011. Geochemistry and groundwater contamination in the La Selva geothermal system (Girona, Northeast Spain). Geothermics 40, 275-285.

Pasvanoglu, S., Chandrasekharam, D., 2011. Hydrogeochemical and isotopic study of thermal and mineralized waters from the Nevsehir (Kozakli) area, Central Turkey. J. Volcanol. Geoth. Res. 202, 241-250.

Pedley, H.M., 1990. Classification and environmental models of cool freshwater tufas. Sediment. Geol. 68, 143-154.

Pedley, H.M., 2009. Tufas and travertines of the Mediterranean region: a testing ground for freshwater carbonate concepts and developments. Sedimentology 56, 221-246

Pentecost, A., 1995. The quaternary travertine deposits of Europe and Asia minor. Quat. Sci. Rev. 14, 1005-1028.

Pentecost, A., 2005. Travertine. Springer, Berlin, p. 445.

Pola, M., Gandin, A., Tuccimei, P., Soligo, M., Deiana, R., Fabbri, P., Zampieri, D., 2014. A multidisciplinary approach to understanding carbonate deposition under tectonically controlled hydrothermal circulation: A case study from a recent travertine mound in the Euganean hydrothermal system, northern I taly. Sedimentology 61, 172-199.

Rainey, D.K., Jones, B., 2009. Abiotic versus biotic controls on the development of the Fairmont Hot Springs carbonate deposit, British Columbia, Canada. Sedimentology 56, 1832-1857.

Ricci, M., Bertini, A., Capezzuoli, E., Horvatinčić, N., Andrews, J.E., Fauquette, S., Fedi, M., 2015. Palynological investigation of a Late Quaternary calcareous tufa and travertine deposit: A case study of Bagnoli in the Valdelsa Basin (Tuscany, central Italy). Review of Palaeobotany and Palynology 218, 184-197.

Riding, R., 1991. Classification of microbial carbonates. - In: Riding, R. (ed.): Calcareous algae and stromatolites 21-51, Berlin (Springer).

Rihs, S., Condomines, M., Poidevin, J.L., 2000. Longterm behaviour of continental hydrothermal systems: Useries study of hydrothermal carbonates 
from the French Massif Central (Allier Valley). Geochim. Cosmochim. Acta 418, 3189-3199.

Rimondi, V., Costagliola, P., Ruggieri, G., Benvenuti, M., Boschi, C., Brogi, A., Capezzuoli, E., Morelli, G., Gasparon, M., Liotta, D., 2016. Investigating fossil hydrothermal systems by means of fluid inclusions and stable isotopes in banded travertine: an example from Castelnuovo dell'Abate (southern Tuscany, Italy). Int. J. Earth Sci. 105 (22), 659-679. http://dx.doi.org/10.1007/s00531-015-1186-y.

Rogerson, H.M., Pedley, M., Kelham, A., Wadhawan, J.D., 2014. Linking mineralisation process and sedimentary product in terrestrial carbonates using a solution thermodynamic approach. Earth Surface Dynamics 2: p. 197-216.

Rolland, A., Toussaint, R., Baud, P., Schmittbuhl, J., Conil, N., Koehn, D., Renard, F., Gratier, J.-P., 2012. Modeling the growth of stylolites in sedimentary rocks. J. Geophys. Res. Solid Earth 117, B06403.

Ronchi, P., Cruciani, F., 2015. Continental carbonates as a hydrocarbon reservoir, an analog case study from the travertine of Saturnia, Italy. AAPG Bulletin 99(4), 711-734.

Rutter, E.H., 1972. The influence of interstitial water on the rheological behaviour of calcite rocks. Tectonophysics 14, 13-33.

Scheuer, G., Schweitzer, F., 1981. Origin of the freshwater limestones of Hungary and comparative studies, Föld. Közl. 111, 67-97.

Schlanger, 1964, In: Sadd, J., Alsharhan. A. 2000. Stylolites in lower cretaceous carbonate reservoir, U.A.E. SEPM Special publication, No. 69, pp 185-207.

Schreiber, B.C., Smith, D., Schreiber, E., 1981. Spring peas from New York State: nucleation and growth of fresh water hollow ooliths and pisoliths. J. Sed. Petrol. 50, 1341-1346.

Selçuk, A.S., Erturaç, M.K., Üner, S., Özsayın, E., Pons-Branchu, E., 2017. Evolution of Çamlık fissure-ridge travertines in the Baskale basin (Van, Eastern Anatolia), Geodinamica Acta 29/1, 1-19.

Sellier, 1979, In: Sadd, J., Alsharhan. A. 2000. Stylolites in lower cretaceous carbonate reservoir, U.A.E. SEPM Special publication, No. 69, pp 185-207. 
Sierralta, M., Kele, S., Melcher, F., Hambach, U., Reinders, J., van Geldern, R., Frechen, M., 2010. Uranium-series dating of travertine from Sutto: implications for reconstruction of environmental change in Hungary. Quatern. Int. 222, 178-193.

Soligo, M., Tuccimei, P., Barberi, R., Delitata, M.C., Miccadei, E., Taddeucci, A., 2002. U/Th dating of freshwater travertine from middle Velino Valley (Central Italy): paleoclimatic and geological implications. Palaeogeogr. Palaeoclimatol. Palaeoecol. 184, 147-161.

Sturchio, N.P., Pierce, K.L., Murrel, M.T., Sorey, M.L., 1994. Uranium series ages of travertines and timing of the Last Glaciation in the Northern Yellowstone Area, Wyoming Montana. Quatern. Res. 41, 265-277.

Taylor, S.R., McLennan, S.M., 1995. The geochemical evolution of the continental crust. Reviews in Geophysics 33, 241-265.

Temiz, U., Eikenberg, J., 2011. U/Th dating of the travertine deposited at transfer zone between two normal faults and their neotectonic significance: Cambazli fissure ridge travertines (the Gediz Graben - Turkey). Geodinamica Acta 24, 95-105.

Temiz, U., Gökten, Y.E., Eikenberg, J., 2013. Strike-slip deformation and U/Th dating of travertine deposition: Examples from North Anatolian Fault Zone, Bolu and Yeniçağ Basins, Turkey. Quaternary International 12, 132-140.

Temiz, U., Gökten., E, Eikenberg, J., 2009. U/Th dating of fissure ridge travertines from the Kirsehir region (Central Anatolia Turkey): structural relations and implications for the Neotectonic development of the Anatolian block. Geodinamica Acta 22, 201-213.

Török, Á., Mindszenty,A., Claes, H., Kele, S., Fodor, L., Swennen, R., 2017. Geobody architecture of continental carbonates: "Gazda" travertine quarry (Süttő, Gerecse Hills, Hungary), Quat. Int., 1-22.

Tucker., M., 1988. Sedimentary Petrology. An Introduction. Blackwell Scientific Publication, $252 \mathrm{p}$.

Uysal, I.T., Feng, Y., Zhao, J.X., Altunel, E., Weatherley, D., Karabacak, V., Cengiz, O., Golding, S.D., Lawrence, M.G., Collerson, K.D., 2007. U-series dating and geochemical tracing of late Quaternary travertine in co-seismic fissures. Earth Planet. Sci. Lett. 257, 450-462.

Uysal, I.T., Feng, Y., Zhao, J., Isik, V., Nuriel, P., Golding, S., 2009. 
Hydrothermal $\mathrm{CO} 2$ degassing in seismically active zones during the late Quaternary. Chem. Geol. 265, 442-454.

Uysal, I.T., Feng, Y., Zhao, J., Bolhar, R., Isik, V., Baublys, K.A., Yago, A., Golding, S.D., 2011. Seismic cycles recorded in late Quaternary calcite veins: geochronological, geochem- ical and microstructural evidence. Earth Planet. Sci. Lett. 303, 84-96.

Veysey, J., Goldenfeld, N. 2008. Watching rocks grow, 4, 310-313.

Violante, C., D'Argenio, B., Ferreri, V., Golubic, S., 1994a. Sedimentary Model of Quaternary Travertine deposits. Abstracts, IAS 15th Reg.Meeting, Ischia (Italy), 426-428.

Violante, C., Ferreri, V., D'Argenio, B., Golubic, S., 1994b. Quaternary Travertines at Rochetta a Volturno (I sernia, Central Italy). Facies Analysis and Sedimentary Model of an Organogenic Carbonate System. Excursion A1, in: Pre-Meeting Fieldtrip Guidebook, IAS 15th Reg.Meeting, Ischia (Italy), 5-23.

Walker, M. 2005. Quaternary dating methods. Wiley (England)

Warren, J.K., 1999. Evaporites: their evolution and economics. Blackwell Scientific, Oxford, UK. 438 p.

Warren, J.K., 2006. Evaporites: Sediments, Resources and Hydrocarbons. Springer, Berlin. $1036 \mathrm{p}$.

Warwick, G.T., 1952. Rimstone pools and associated phenomena. Trans Cave Res Group GB 2, 153-165.

Shipton, Z.K., Evans, J.P., Dockrill, B., Heath, J., Williams, A., Kirchner, D., Kolesar, P.T., 2005. Natural leaking $\mathrm{CO}_{2}$-charged systems as analogs for failed geologic storage reservoirs, in: D. Thomas (Ed.), Carbon Dioxide Capture for Storage in Deep Geologic Formations - Results from the $\mathrm{CO}_{2}$ Capture Projectvol. 2, Elsevier Science (2005), pp. 699-712.

Zentmyer, R., Myrow, P.M., Newell, D.L., 2008. Travertine deposits from along the South Tibetan Fault System near Nyalam, Tibet. Geol. Mag. 145, 753-765.

\section{Figure Captions}

Fig. $1-$ a) Terraced depositional system at Saturnia (Italy) with pools and 
rims, where calcite crystallize as a result of $\mathrm{CO}_{2}$ degassing from flowing carbonate-rich thermal waters; b) example of crystalline layers (crystalline crusts) deposited on the slope system and formed by dendritic calcite crystals; c) detail of the crystalline crusts indicated in (b). d-e) Example of a slope microterraced deposit formed by dendritic calcite crystals forming crystalline crusts (the so-called "chimney-like veins" by Billi et al., 2017); e-f) details of the inset in (e): note the different shape of the crystal-fans along the same level, emphasizing that that the direction of the calcite crystal growth cannot be based on the fan-like crystal arrangements as proposed by Billi et al. (2017).

Fig. 2 - Present-day depositional systems and related macro-facies. a) Terraced slope depositional system at Pamukkale (Turkey); b) Terraced slope depositional system at Karahayıt (Turkey); note the stepped morphology of the terraced slope with metre-scale pools separated by round rims at the pool margin and vertical walls. c-d) Detail of a pool (indicated in b) illustrating the site of precipitation of travertine with different fabrics, such as shrubs, radial pisoids and coated gas bubbles (cf Guo and Riding, 1998); e) micro-terraced slope system; f) detail of microterraces showing pools and rims, where the rims are built by crystalline dendrites and pools are sites of precipitation of different travertine fabrics such as shrubs and porous travertine (e.g. coated gas bubbles).

Fig. 3 - Examples of banded calcite veins filling cracks that cut across layers or follow bedding surfaces; a) banded calcite vein crossing late Pleistocene travertine layers at Bagno Vignoni (southern Tuscany, Italy); b) banded calcite veins system crossing a Pleistocene fissure ridge-type travertine deposit (Akköy fissure-ridge) in the Denizli Basin (Turkey; c) banded calcite vein filling a sub-vertical fracture in the wall of the Akköy fissure ridge from Denizli Basin (Turkey); d) detail of the inset indicated in (b); e) banded calcite veins system filling sub-vertical fractures crossing the middle Pleistocene fissure ridge-type travertine deposit (Çukurbağ fissureridge) in the Denizli Basin (Turkey; f) detail of the inset indicated in (e); g) sub-horizontal banded calcite vein filling a fracture sub-parallel to the bedding surfaces in the late Pleistocene-Holocene travertine deposits at Cava Campo Muri (Rapolano Terme, Italy); h) Sub-horizontal and lowangle banded calcite veins system filling a fracture that cut across layers or follow bedding surfaces in the late-Pleistocene-Holocene travertine deposits at Cava Campo Muri (Rapolano Terme, Italy); i) detail of the inset indicated in $(\mathrm{h})$. 
Fig. 4 - Photomicrographs of microfabrics of crystalline crusts and banded calcite veins filling fractures cutting across travertine beds. a-b) example of crystalline crust from Rapolano Terme (Italy); c-d) example of banded calcite vein from the Denizli Basin (Turkey). Please note fabric, dimension and crystal morphology that are different from the interpreted veins by Billi et al. (2017). Many other examples of micro-fabrics are illustrated in numerous publications (Gandin and Capezzuoli, 2014; Della Porta, 2015; Croci et al., 2016; Della Porta et al., 2017 and references therein) to which the readers are addressed for more details.

Fig. 5 - Photographs of saw-cut walls exposed in the Pianetti quarry near Saturnia (southern Tuscany, I taly), the same outcrops reported in Billi et al. 2017. a-b) Slope deposit formed by crystalline crusts giving rise to terraces in a prograding pools system (the so-called "chimney-like veins" by Billi et al. 2017, enlarged in c) and the final slope accumulation. The slope deposit is unconformably overlain by subhorizontal porous strata formed by shrub facies (typical of subhorizontal pools) terminating in onlap against the slope depositional profile. c) Decimeter-scale pools and rims characterized by prograding and aggrading different fabric types. d) Cross-section of a progradational terraced slope with pools bordered by round rims prograding and aggrading. The terraced system is unconformably overlain by subhorizontal strata onlapping against the pool rims: this geometric configuration is a primary depositional feature and should not be explained as a secondary features (i.e. the result of syndiagenetic folds caused by laterally-confined volume expansion through hydrothermal incremental veining) as proposed by Billi et al. (2017) because the subhorizontal porous strata in onlap do not appear deformed by the alleged syn-diagenetic folding.

Fig. 6 - a) Irregular geometrical setting of travertine beds visible in saw-cut walls exposed in the Pianetti quarry near Saturnia (southern Tuscany, Italy), and interpreted by Billi et al. (2017) as the result of refold structures (cf their Fig. S10); b) Example of an active cascade travertine depositional system at Bagni San Filippo (southern Tuscany, Italy), where the sub-vertical slopes explain the geometrical setting of the travertine beds illustrated in (a) and interpreted by Billi et al. (2017) as secondary fold structures (i.e. refolded structures). c) Cross-section of a terraced slope; d) saw-tooth shape of travertine layers deriving from an orthogonal cross-section of the terraced slope: the saw-tooth shape is the result of the progradational growth of the microterraced slope. 


\section{ACCEPTED MANUSCRIPT}

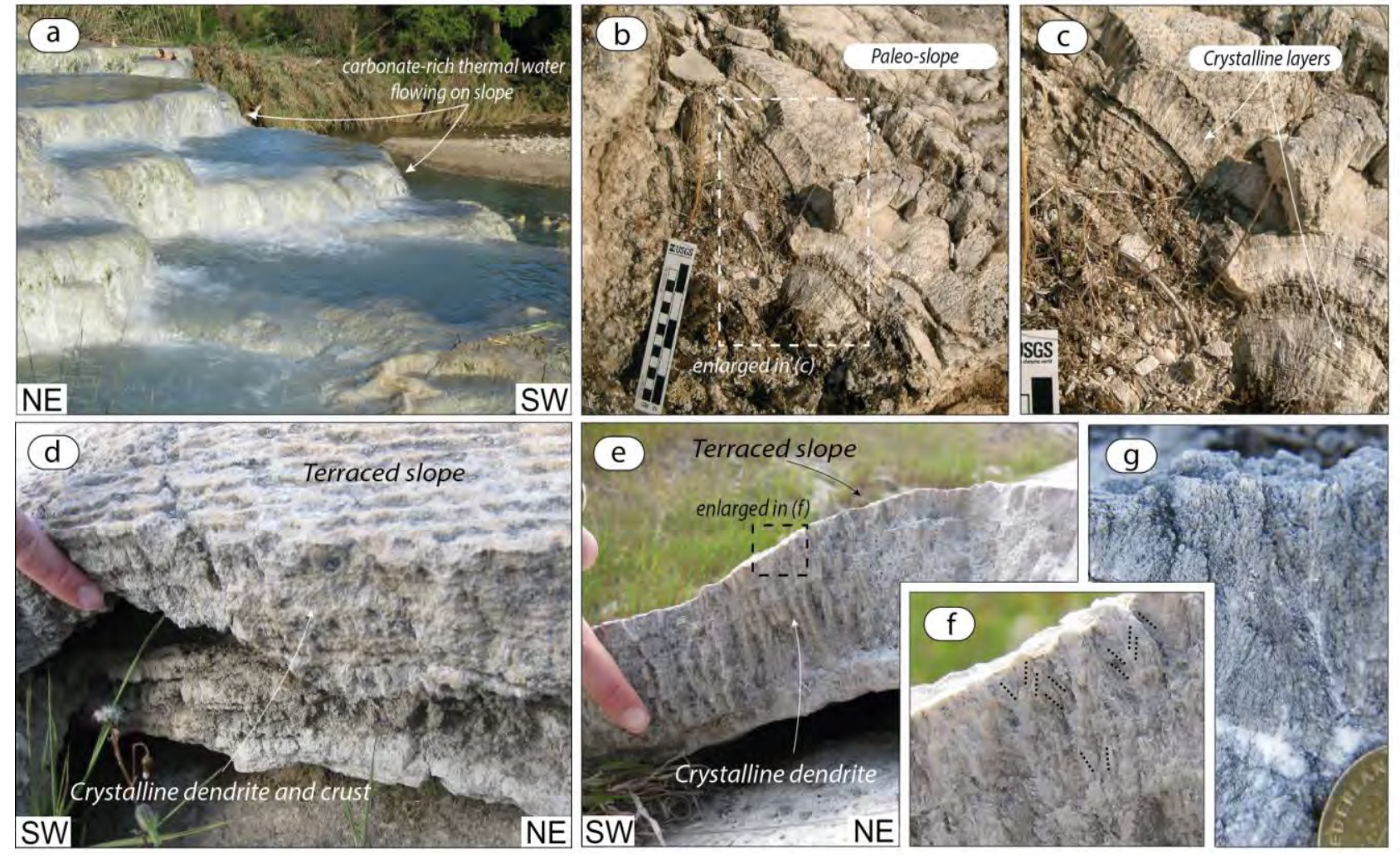

Fig. 1 - a) Terraced depositional system at Saturnia (Italy) with pools and rims, where calcite crystallize as a result of $\mathrm{CO} 2$ degassing from flowing carbonate-rich thermal waters; b) example of crystalline layers (crystalline crusts) deposited on the slope system and formed by dendritic calcite crystals; c) detail of the crystalline crusts indicated in (b). d-e) Example of a slope microterraced deposit formed by dendritic calcite crystals forming crystalline crusts (the so-called "chimney-like veins" by Billi et al., 2017); e-f) details of the inset in (e): note the different shape of the crystal-fans along the same level reinforcing the fact that the direction of the calcite crystal growth cannot be based on the fans-like crystal arrangement as proposed by Billi et al. (2017).

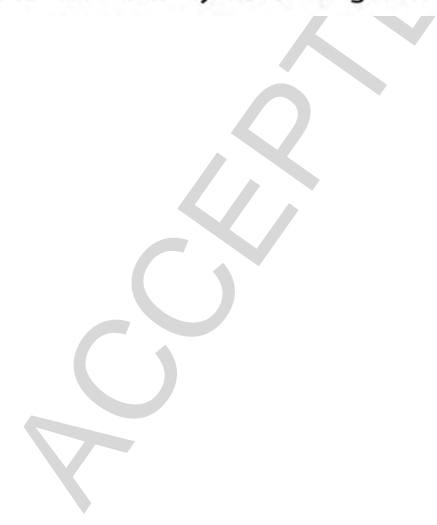




\section{ACCEPTED MANUSCRIPT}

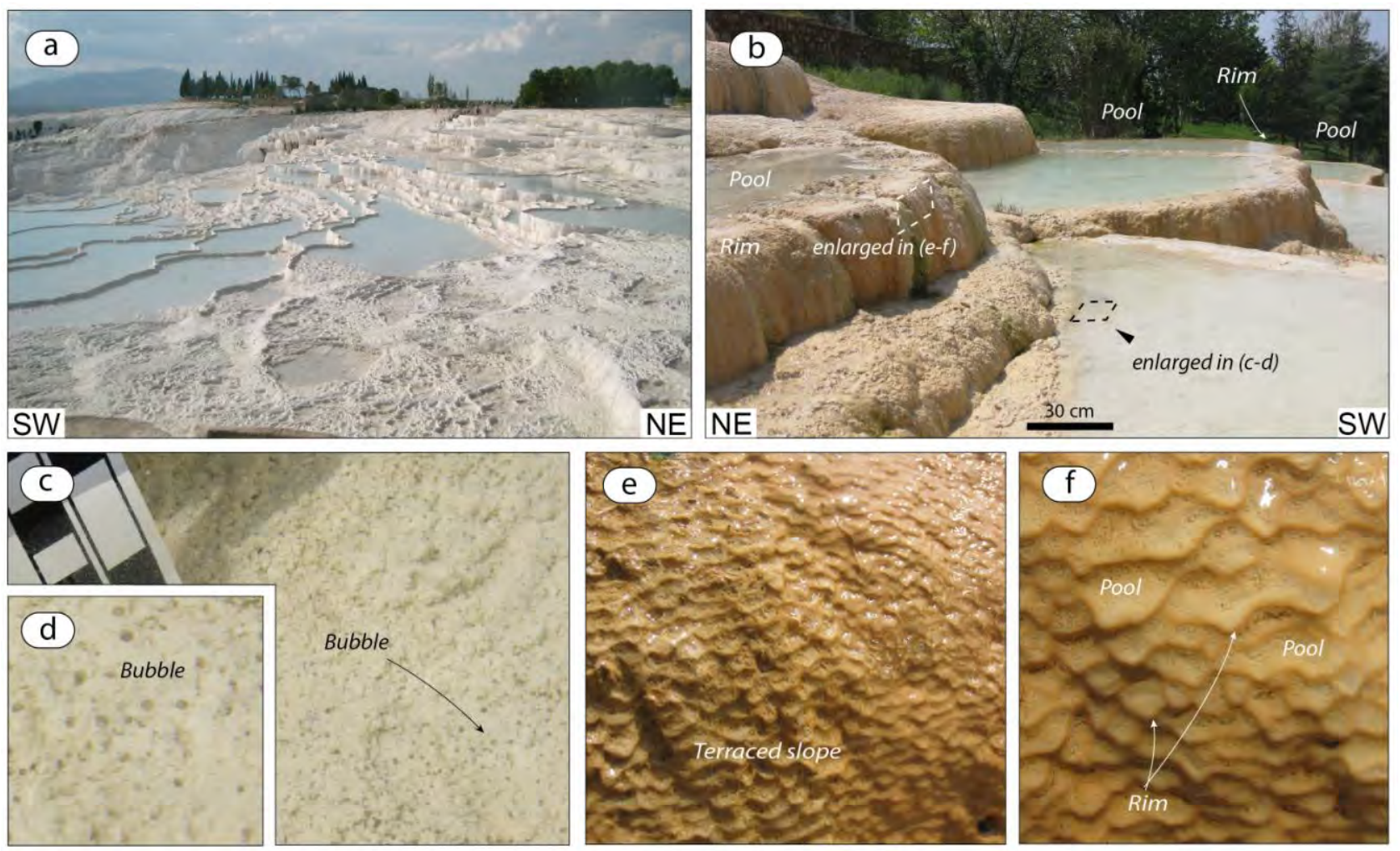

Fig. 2 - Present-day depositional systems and related macrofacies. a) Terraced slope depositional system at Pamukkale (Turkey); b) Terraced slope depositional system at Karahayıt (Turkey); note the stepped morphology of the terraced slope with metre-scale pools separated by rounded rim at the pool margin, and vertical walls. c-d) Detail of a pool (indicated in b) illustrating the site of precipitation of travertine with different fabrics, such as shrubs, radial pisoids and coated gas bubbles (cf Guo and Riding, 1998); e) microterraced slope system; f) detail of microterraces showing pools and rims, where the rims are built by crystalline dendrites and pools are sites of precipitation of different travertine fabrics such as shrubs and porous travertine (e.g. coated gas bubbles).

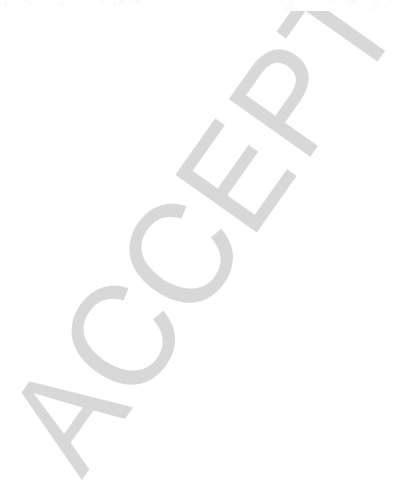



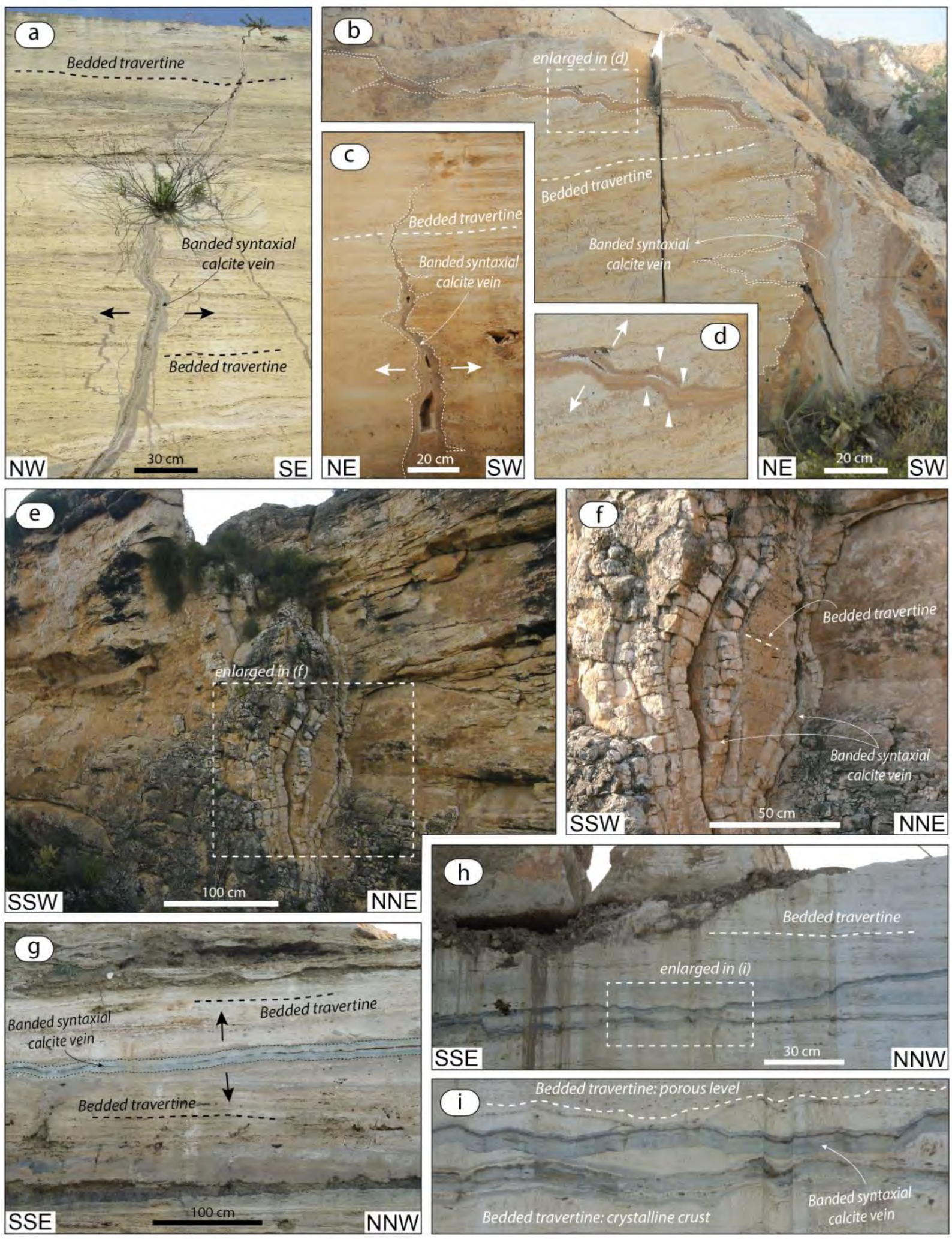

Fig. 3 - Examples of banded calcite veins filling cracks that cut across layers or follow bedding surfaces; a) banded calcite vein crossing late Pleistocene travertine layers at Bagno Vignoni (southern Tuscany, Italy); b) banded calcite veins system crossing a Pleistocene fissure ridge-type travertine deposit (Akköy fissure-ridge) in the Denizli Basin, southwestern Turkey; c) banded calcite vein filling a sub-vertical fracture in the wall of the Akköy fissure ridge (Denizli Basin, southwestern Turkey); d) detail of the inset indicated in (b); e) banded calcite veins system filling sub-vertical fractures crossing the middle Pleistocene fissure ridge-type travertine deposit (Çukurbağ fissure-ridge) in the Denizli Basin, southwestern Turkey; $f$ ) detail of the inset indicated in (e); g) sub-horizontal banded calcite vein filling a fracture sub-parallel to the bedding surfaces in the late Pleistocene-Holocene travertine deposits at Cava Campo Muri (Rapolano Terme, Italy); h) Sub-horizontal and low-angle banded calcite veins system filling a fracture that cut across layers or follow bedding surfaces in the Late-Pleistocene-Holocene travertine deposits at Cava Campo Muri (Rapolano Terme, Italy); i) detail of the inset indicated in (h). 

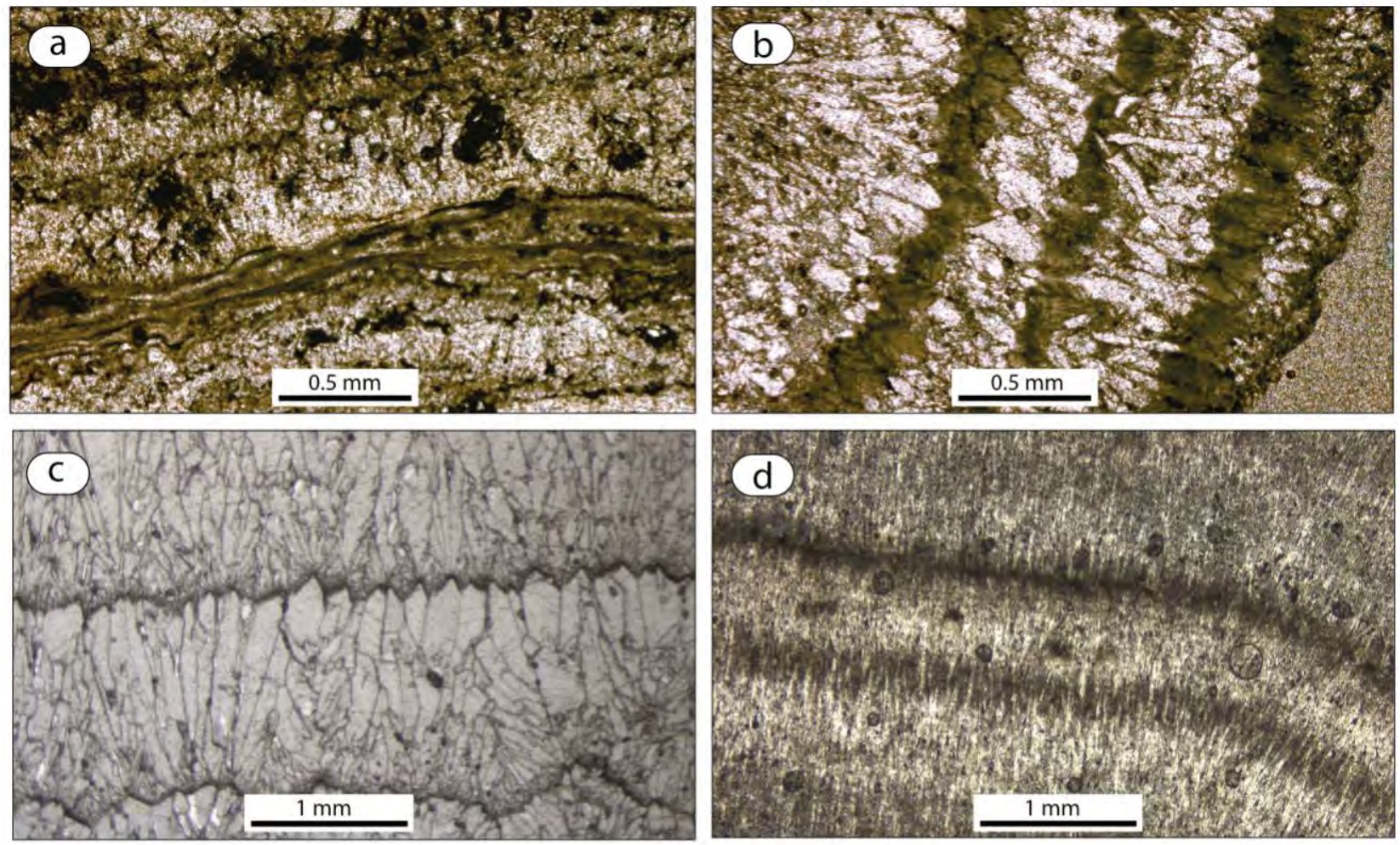

Fig. 4 - Photomicrographs of microfabrics of crystalline crusts and banded calcite veins filling fractures cutting across travertine beds. $a-b$ ) example of crystalline crust from Rapolano Terme (Italy); c-d) example of banded calcite vein from the Denizli Basin (Turkey). Please note the differences in fabric, dimension and crystal morphology. Many other examples of microfabrics are illustrated in numerous publications (Gandin and Capezzuoli, 2014; Della Porta, 2015; Croci et al., 2016; Della Porta et al., 2017 and references therein) to which the readers are addressed for more details. 


\section{ACCEPTED MANUSCRIPT}
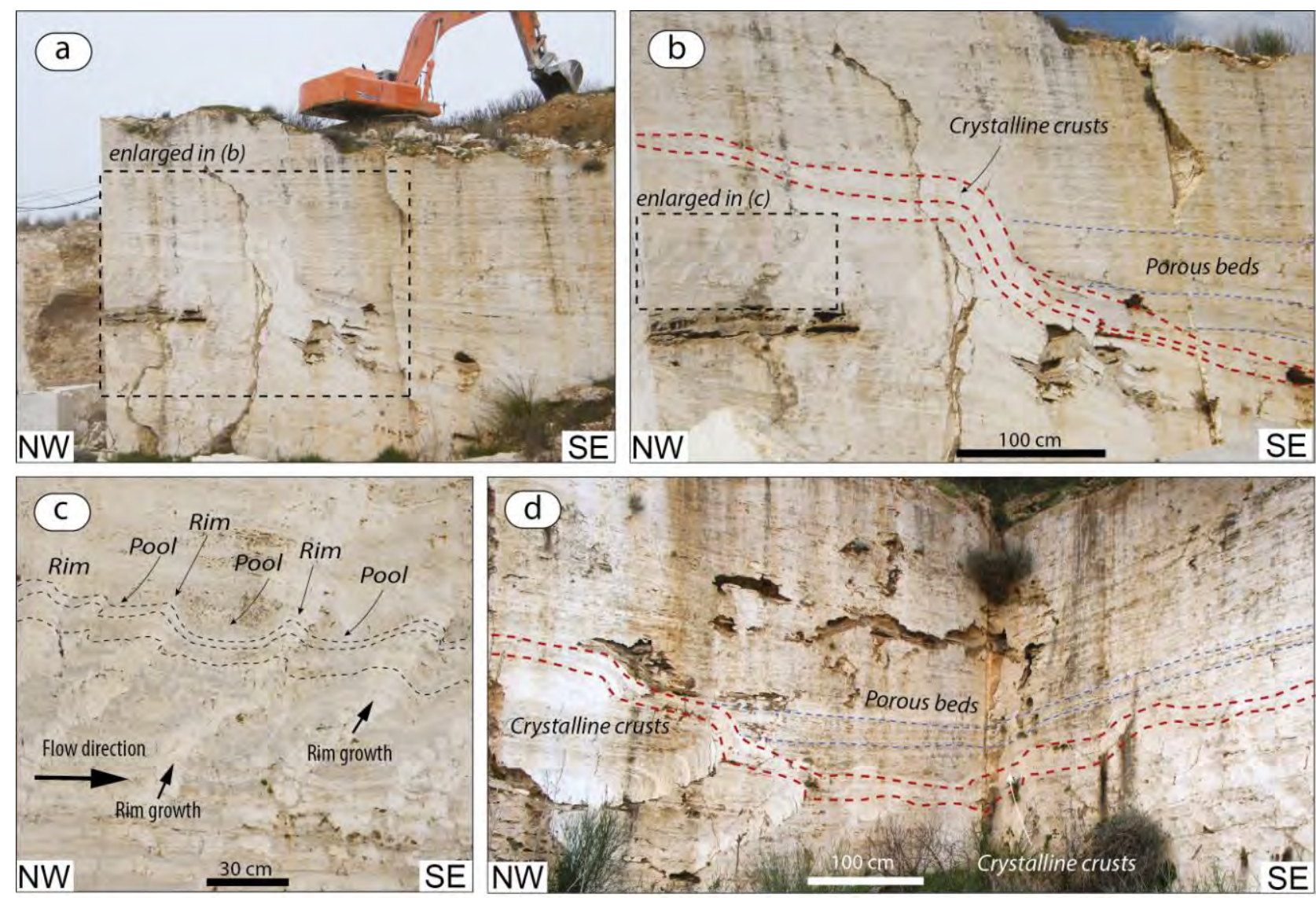

Fig. 5 - Photographs of saw-cut walls exposed in the Pianetti quarry near Saturnia (southern Tuscany, Italy), the same outcrops reported in Billi et al. 2017.

a-b) Slope deposit formed by crystalline crusts giving rise to terraces in a prograding pools system (the so-called "chimney-like veins" by Billi et al. 2017, enlarged in c) and the final slope accumulation. The slope deposit is unconformably overlain by subhorizontal porous strata formed by shrub facies (typical of subhorizontal pools) terminating in onlap against the slope depositional profile. c) Decimeter-scale pools and rims characterized by prograding and aggrading different fabric types. d) Cross-section of a progradational terraced slope with pools bordered by rounded rims prograding and aggrading. The terraced system is unconformabily overlain by subhorizontal strata onlapping against the pool rims: this geometric configuration is a primary depositional feature and cannot be explained as a secondary features (i.e. the result of syn-diagenetic folds caused by laterally-confined volume expansion through hydrothermal incremental veining) as proposed by Billi et al. (2017) because the subhorizontal porous strata in onlap do not appear deformed by the alleged syn-diagenetic folding. 

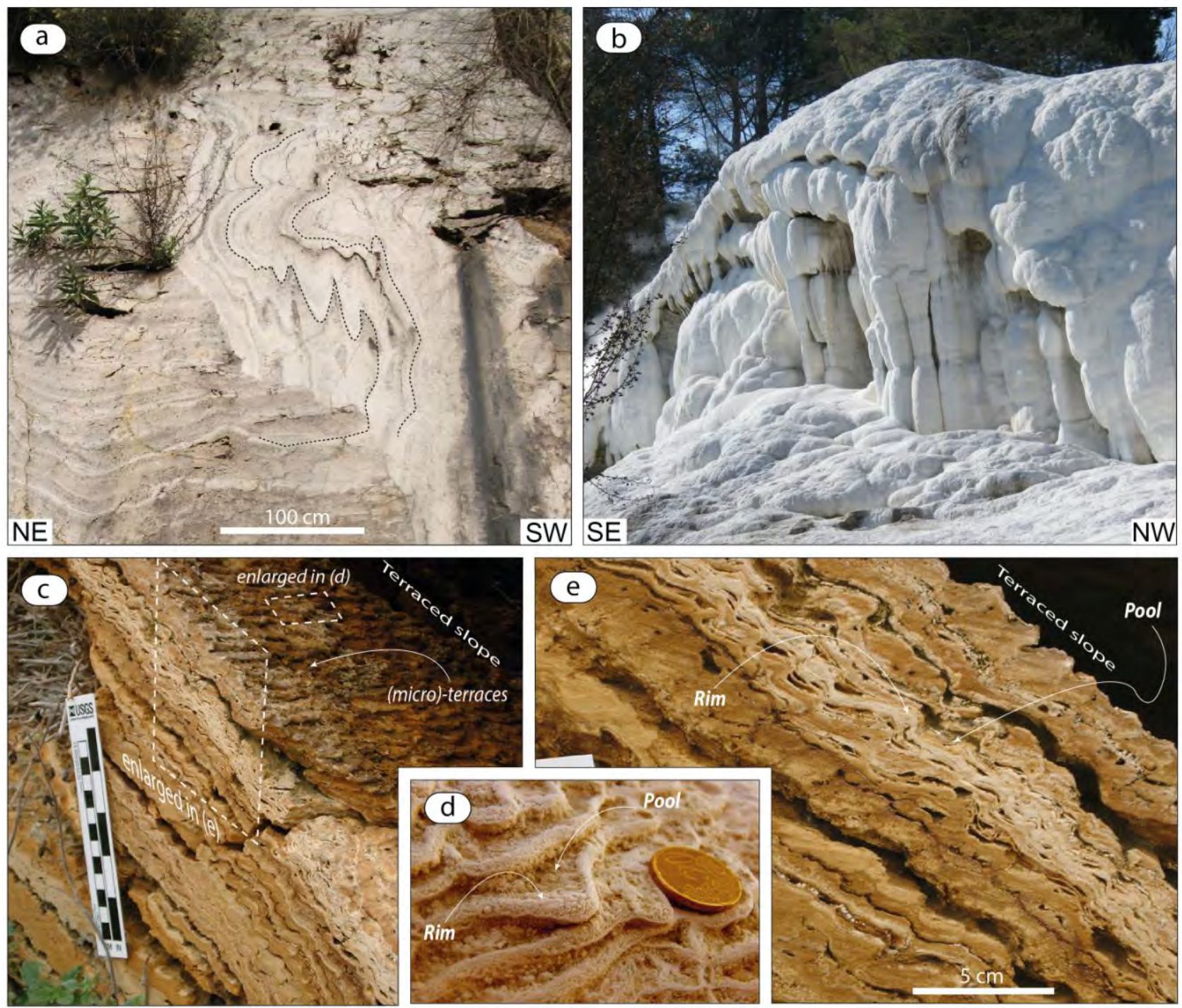

Fig. 6 - a) Irregular geometrical setting of travertine beds visible in saw-cut walls exposed in the Pianetti quarry near Saturnia (southern Tuscany, Italy), and interpreted by Billi et al. (2017) as the result of refold structures (cf their Fig. S10); b) Example of an active cascade travertine depositional system at Bagni San Filippo (southern Tuscany, Italy), where the sub-vertical slopes explain the geometrical setting of the travertine beds illustrated in (a) and interpreted by Billi et al. (2017) as secondary fold structures (i.e. refolded structures). c) Cross-section of a terraced slope; d) saw-tooth shape of travertine layers deriving from an orthogonal cross-section of the terraced slope: the saw-tooth shape is the result of the progradational growth of the microterraced slope. 


\section{Highlights}

The origin of some travertine beds, interpreted by Billi et al. (2017) as the result of incremental hydrothermal veining, is discussed.

Travertine folding, interpreted by Billi et al. (2017) as the result of laterallyconfining volume expansion caused by incremental hydrothermal veining, is discussed.

Age rejuvenation of travertine deposits and modification of travertine strength and porosity, proposed by Billi et al. (2017), is discussed.

Refold stuctures, stylolite and tectonic foliation affecting travertine beds, as described by Billi et al. (2017), is discussed. 


\section{Accepted Manuscript}

Comment on "First records of syn-diagenetic non-tectonic folding in Quaternary thermogene travertines caused by hydrothermal incremental veining" by Billi et al. Tectonophysics 700-701 (2017) 60-79

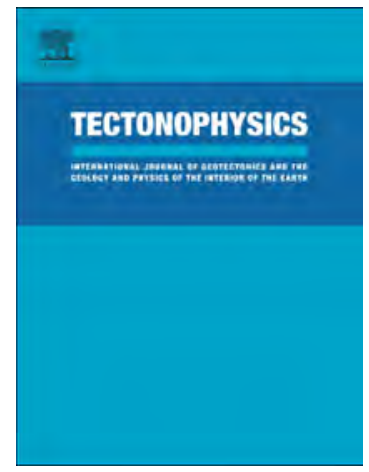

M. Cihat Alçiçek, Hülya Alçiçek, Erhan Altunel, Concha Arenas, Paul Bons, Andrea Brogi, Enrico Capezzuoli, Tamara de Riese, Giovanna Della Porta, Anna Gandin, Li Guo, Brian Jones, Volkan Karabacak, Stephen Kershaw, Domenico Liotta, Andrea Mindszenty, Martyn Pedley, Paola Ronchi, Rudy Swennen, Ugur Temiz

PII: S0040-1951(17)30362-1

DOI: doi: 10.1016/j.tecto.2017.09.002

Reference: TECTO 127615

To appear in: Tectonophysics

Received date: $\quad 3$ May 2017

Revised date: 29 August 2017

Accepted date: $\quad 2$ September 2017

Please cite this article as: M. Cihat Alçiçek, Hülya Alçiçek, Erhan Altunel, Concha Arenas, Paul Bons, Andrea Brogi, Enrico Capezzuoli, Tamara de Riese, Giovanna Della Porta, Anna Gandin, Li Guo, Brian Jones, Volkan Karabacak, Stephen Kershaw, Domenico Liotta, Andrea Mindszenty, Martyn Pedley, Paola Ronchi, Rudy Swennen, Ugur Temiz , Comment on "First records of syn-diagenetic non-tectonic folding in Quaternary thermogene travertines caused by hydrothermal incremental veining" by Billi et al. Tectonophysics 700-701 (2017) 60-79, Tectonophysics (2017), doi: 10.1016/ j.tecto.2017.09.002

This is a PDF file of an unedited manuscript that has been accepted for publication. As a service to our customers we are providing this early version of the manuscript. The manuscript will undergo copyediting, typesetting, and review of the resulting proof before it is published in its final form. Please note that during the production process errors may be discovered which could affect the content, and all legal disclaimers that apply to the journal pertain. 